\title{
Role of endothelin-1 and its receptors in cerebral vasospasm following subarachnoid hemorrhage
}

\author{
YA-WEN CHENG ${ }^{1}$, WEN-JUAN LI ${ }^{2}$, XIANG-JUN DOU ${ }^{3}$, RUI JIA ${ }^{1}$, HUA YANG $^{4}$, XIN-GUANG LIU ${ }^{4}$, \\ CANG-BAO XU ${ }^{5}$, JING LIU ${ }^{6}$, YONG-XIAO CAO ${ }^{6}$ and GUO-GANG LUO ${ }^{1}$
}

\begin{abstract}
${ }^{1}$ Department of Neurology, First Affiliated Hospital, Xi'an Jiaotong University Health Science Center, Xi'an, Shaanxi 710061; ${ }^{2}$ Department of Neurology, Second Affiliated Hospital, Lanzhou University, Lanzhou, Gansu 730030; ${ }^{3}$ Department of Neurology, Xi'an Children's Hospital, Xi'an, Shaanxi 710002; ${ }^{4}$ State Key Laboratory of Natural Medicines, China Pharmaceutical University, Nanjing, Jiangsu 210009; ${ }^{5}$ Shaanxi Key Laboratory of Ischemic Cardiovascular Disease, Institute of Basic and Translational Medicine, Xi'an Medical University, Xi'an, Shaanxi 710021; ${ }^{6}$ Department of Pharmacology, Xi'an Jiaotong University Health Science Center, Xi'an, Shaanxi 710061, P.R. China
\end{abstract}

Received November 22, 2017; Accepted August 29, 2018

DOI: $10.3892 / \mathrm{mmr} .2018 .9513$

\begin{abstract}
Cerebral vasospasm (CVS) is a severe complication of subarachnoid hemorrhage (SAH), and endothelin-1 (ET-1) may be involved in its pathogenesis. The present study aimed to investigate the expression of ET-1 in cerebrospinal fluid (CSF) in patients with SAH and to analyze rat arterial contractility and the expression levels of ET-1 receptors in vitro. CSF samples were collected from 28 patients and the expression levels of ET-1 were measured. Rat cerebral basilar arteries were isolated and incubated with hemorrhagic or clear CSF. Contractility, as well as $\mathrm{ET}_{\mathrm{A}}$ and $\mathrm{ET}_{\mathrm{B}}$ mRNA expression were measured. ET-1 levels in CSF increased and reached a peak within the initial 5 days after SAH onset and then gradually subsided. After 12 or $24 \mathrm{~h}$, the contraction of arteries incubated in hemorrhagic CSF was substantially stronger than those in clear CSF. The mRNA expression levels of endothelin receptor type A and B in arteries incubated in hemorrhagic CSF were significantly higher than those in clear CSF. ET-1 and its receptors may be involved in the pathogenic mechanism of CVS following SAH. ET-1 expression in CSF may be used as a marker in CVS and its receptors may provide novel therapeutic targets in CVS.
\end{abstract}

\section{Introduction}

Subarachnoid hemorrhage $(\mathrm{SAH})$ refers to bleeding within the subarachnoid space, which is a critical condition with high

Correspondence to: Dr Guo-Gang Luo, Department of Neurology, First Affiliated Hospital, Xi'an Jiaotong University Health Science Center, 277 Yanta West Road, Xi'an, Shaanxi 710061, P.R. China E-mail: lguogang@163.com

Key words: subarachnoid hemorrhage, cerebral vasospasm, cerebrospinal fluid, endothelin-1, endothelin receptor morbidity and mortality. The annual incidence of SAH has been estimated to be approximately $9 / 100,000$ in the general population, worldwide (1). Cerebral vasospasm (CVS) is one of the most serious complications of SAH and is an independent risk factor for poor prognosis (2). CVS most commonly occurs within 3 to 15 days from the onset of SAH, and reaches peak severity between 7 and 10 days. CVS is characterized by upregulated vasoconstrictor and downregulated vasodilator expression, as well as vascular smooth muscle cell hypercontractility (3).

Endothelin-1 (ET-1) is a potent vasoconstrictor peptide of endothelial origin and may be associated with the pathogenesis of CVS following aneurysmal SAH (4). ET-1-induced vasoconstriction is mediated by two G-protein-coupled receptors: Endothelin receptor type $\mathrm{A}\left(\mathrm{ET}_{\mathrm{A}}\right)$ and endothelin receptor type $\mathrm{B}\left(\mathrm{ET}_{\mathrm{B}}\right)$ (5). In experimental animal models of $\mathrm{SAH}$, it has been demonstrated that cerebral arteries are more sensitive to ET-1 (6,7), and increased levels of $\mathrm{ET}_{\mathrm{A}}$ and $\mathrm{ET}_{\mathrm{B}}$ mRNA have been reported $(8,9)$. Additionally, ET-1 receptor antagonists, particularly antagonists of both $\mathrm{ET}_{\mathrm{A}}$ and $\mathrm{ET}_{\mathrm{B}}$ receptors, prevent and relieve SAH-induced CVS $(10,11)$. Some scholars have speculated that increased levels of ET-1 in the cerebrospinal fluid (CSF) of patients with SAH may induce hypercontractility in cerebral arteries, thereby contributing to the occurrence of CVS (12).

The present study aimed to investigate the expression levels of ET-1 in the CSF of patients with aneurysmal SAH. In addition, arterial contractility and ET-1 receptor expression $\left(\mathrm{ET}_{\mathrm{A}}\right.$ and $\left.\mathrm{ET}_{\mathrm{B}} \mathrm{mRNA}\right)$ was analyzed in vitro. Based on the present study, the therapeutic applications of the antagonist for ET-1 receptors should be assessed in further studies.

\section{Materials and methods}

Participants and CSF sample collection. The present study was approved by the Institutional Review Board and Ethics Committee of the First Affiliated Hospital of Xi'an Jiaotong University (Xi'an, China; approval no. 2016-074). A total of 
16 patients were enrolled, who were diagnosed with aneurysmal SAH based on computed tomography (CT) and/or digital subtraction angiography (DSA) evidence. The individual clinical severity of SAH was assessed according to the World Federation of Neurological Surgeons scale and the Fisher CT grading system $(13,14)$. Additionally, 12 patients with hydrocephalus were enrolled as controls.

The inclusion criteria were as follows: i) Between the ages of 18 and 80 years old; ii) diagnosed with aneurysmal SAH by CT and/or DSA; iii) admission with-in $48 \mathrm{~h}$ from onset of SAH; iv) Fisher grade III or IV, which is radiologically typical and prone to CVS (14); and v) consent to participate was provided.

CSF samples were collected from patients with aneurysmal $\mathrm{SAH}$ and hydrocephalus, which were classified into a SAH group and NPH group, respectively. All CSF samples were obtained via lumbar puncture or lumbar subarachnoid space catheter. The CSF samples were collected within seven-point time frame covering 0-10 days after the onset of SAH. All CSF samples were centrifuged at $(4,130 \mathrm{x} \mathrm{g})$ for $15 \mathrm{~min}$ at room temperature, following which the supernatant was frozen at $-80^{\circ} \mathrm{C}$. The hemorrhagic CSF samples can be diluted by fresh-made MOPS buffer into different concentrations, including 25 and $50 \%$.

Measurement of ET-1 levels. ET-1 concentrations in CSF samples were measured using an ELISA kit (cat. no. F20030; Shanghai Xitang Biotechnology Co., Ltd., Shanghai, China) at the National Key Laboratory of China Pharmaceutical University.

Animal selection and artery incubation. Animal experiments were approved by the Animal Experiment Management Committee of Xi'an Jiaotong University (Xi'an, China), and all measures were taken to minimize animal discomfort. Specific pathogen-free Sprague-Dawley rats (age, 6-months; weight, 300-400 g; 30 males and 30 females) were provided by the Experimental Animal Center of Xi'an Jiaotong University (Xi'an, China). The rats were maintained in a controlled facility at $25^{\circ} \mathrm{C}$ and $50 \%$ humidity, under a $12 \mathrm{~h}$ light/dark cycle with free access to standard chow and water.

The rats were sacrificed by carbon dioxide overdose followed by cervical dislocation. The brain was immediately removed and immersed in fresh-made ice-cold MOPS buffer. Its constituents are shown in Table I. The cerebral basilar arteries were isolated using a stereomicroscope and were subsequently cut into segments of approximately $1 \mathrm{~mm}$ in length. The artery segments were put in a culture plate with $2 \mathrm{ml}$ medium (hemorrhagic CSF or clear CSF from SAH and hydrocephalus patients, respectively) containing antibiotics (1x10 $\mathrm{U} / 1$ penicillin and $100 \mathrm{mg} / 1$ streptomycin). The culture plate was put into a box with a constant temperature of $37^{\circ} \mathrm{C}$, which was continuously ventilated with $5 \% \mathrm{CO}_{2}$ for 6,12 or $24 \mathrm{~h}$.

In vitro myographic experiments. Artery segments were placed in MOPS fluid and threaded by two filaments (diameter, $40 \mu \mathrm{m}$ ) prior to mounting in a small vessel PowerLab myograph (Danish Myo Technology A/S, Aarhus, Denmark). One filament was connected to a tension transducer linked
Table I. Constituents of MOPS buffer and $63.5 \mathrm{mM} \mathrm{K}{ }^{+}$MOPS buffer (/L).

\begin{tabular}{lcc}
\hline Constituents & MOPS buffer & $\begin{array}{c}63.5 \mathrm{mM} \mathrm{K} \\
\text { MOPS buffer }\end{array}$ \\
\hline $\mathrm{Na}_{2} \mathrm{HPO}_{4} \cdot 12 \mathrm{H}_{2} \mathrm{O}$ & $0.4295 \mathrm{~g}$ & $0.4295 \mathrm{~g}$ \\
$\mathrm{MOPS}$ & $0.418 \mathrm{~g}$ & $0.418 \mathrm{~g}$ \\
$\mathrm{EDTA}$ & $0.006 \mathrm{~g}$ & $0.006 \mathrm{~g}$ \\
$\mathrm{NaCl}$ & $8.15 \mathrm{~g}$ & $4.945 \mathrm{~g}$ \\
$\mathrm{KCl}$ & $0.35 \mathrm{~g}$ & $4.475 \mathrm{~g}$ \\
$\mathrm{CaCl}$ & $0.1775 \mathrm{~g}$ & $0.1775 \mathrm{~g}$ \\
$\mathrm{MgSO}_{4} \cdot 7 \mathrm{H}_{2} \mathrm{O}$ & $0.295 \mathrm{~g}$ & $0.295 \mathrm{~g}$ \\
$\mathrm{Glucose}$ & $1 \mathrm{~g}$ & $1 \mathrm{~g}$ \\
\hline
\end{tabular}

All constituents were dissolved in distilled water and adjusted to $\mathrm{pH}=7.4$ using $\mathrm{NaOH}$ or $\mathrm{HCL}$ to 11 total volume.

to the PowerLab system, and the other was connected to the fine-tuning device that adjusts the distance between the two filaments. Then, the installed vascular rings were laid in a bath chamber containing $5 \mathrm{ml}$ MOPS fluid with continuous ventilation and a $\mathrm{pH}$ of 7.4. All of the vessels were allowed to equilibrate for $30 \mathrm{~min}$ at room temperature. When the baseline was stable, the initial vascular tension was changed to $1.5 \mathrm{mN}$. Following this, $5 \mathrm{ml}$ fresh-made potassium rich $(63.5 \mathrm{mM} \mathrm{K})$ MOPS fluid was added into the bath chamber twice to evaluate contractility. The constituents of $(63.5 \mathrm{mM} \mathrm{K}$ ) MOPS buffer are also shown in Table I. Between the twice potassium rich MOPS buffer, the vessel segments were washed using common MOPS buffer three times. Vessels with a contraction difference of $<10 \%$ were included for further analyses. Finally, ET-1 (ALX-155-001-PC05, Enzo Life Sciences, Inc., Farmingdale, NY, USA) and sarafotoxins 6c (S6c, ET-1 analogue; S6545, Sigma-Aldrich; Merck KGaA, Darmstadt, Germany) were added into the bath chamber at gradually increasing concentrations to obtain the concentration response curves. The concentration of S6c ranged from $10^{-11}$ to $10^{-7.5} \mathrm{~mol} / \mathrm{l}$, while that of ET-1 ranged from $10^{-11}$ to $10^{-7} \mathrm{~mol} / \mathrm{l}$. The contractile response of the vessels was expressed as a percentage of the contraction induced by potassium rich MOPS fluid. The maximal contraction was indicated by $\mathrm{E}_{\max }$, and $\mathrm{pEC}_{50}$ denoted the negative logarithm of the concentration that elicits half of the maximal response.

Detection of $E T_{A}$ and $E T_{B} m R N A$ expression. Total cellular RNA was extracted from rat cerebral arteries, including anterior, middle and posterior cerebral artery as well as basilar artery that had been incubated at $37^{\circ} \mathrm{C}$ for $24 \mathrm{~h}$. Reverse transcription of total RNA to single-stranded cDNA was performed using SuperScipt ${ }^{\mathrm{TM}}$ IV Reverse Transcriptase (18090010, Thermo Fisher Scientific, Inc., Waltham, MA USA) in a $12 \mu 1$ reaction system. RNA was incubated at $65^{\circ} \mathrm{C}$ for $5 \mathrm{~min}$ for denaturation, following which it was immediately cooled on ice. The reverse transcription master mix was added to the tube, and the reaction was performed at $42^{\circ} \mathrm{C}$ for $1 \mathrm{~h}$ and $70^{\circ} \mathrm{C}$ for $5 \mathrm{~min}$. Polymerase chain reaction (PCR) was performed using a SYBR PreMix Ex Taq $^{\mathrm{TM}}$ kit 
Table II. Primer sequences used for polymerase chain reaction.

\begin{tabular}{lll}
\hline Gene & Forward primer sequences $\left(5^{\prime}-3^{\prime}\right)$ & Reverse primer sequences $\left(3^{\prime}-5 '\right)$ \\
\hline $\mathrm{ET}_{\mathrm{A}}$ & GTCGAGAGGTGGCAAAGACC & ACAGGGCGAAGATGACAACC \\
$\mathrm{ET}_{\mathrm{B}}$ & GATACGACAACTTCCGCTCCA & GTCCACGATGAGGACAATGAG \\
$\mathrm{EF}-1_{\alpha}$ & CCCCTCCAGGACGTTTACAAA & CACACGGCCCACAGGTACA
\end{tabular}

$\mathrm{ET}_{\mathrm{A}}$, endothelin receptor type $\mathrm{A} ; \mathrm{ET}_{\mathrm{B}}$, endothelin receptor type $\mathrm{B}$.

Table III. Demographic and clinical data of enrolled patients.

\begin{tabular}{lcc}
\hline Characteristics & SAH group & NPH group \\
\hline Gender (male/female) & $8 / 8$ & $6 / 6$ \\
Age (years) & $52.38 \pm 13.24$ & $30.75 \pm 3.234$ \\
Fisher grade III (n) & 11 & - \\
Fisher grade IV (n) & 5 & - \\
Hunt-Hess grade II-III (n) & 12 & - \\
Hunt-Hess grade IV-V (n) & 4 & - \\
\hline
\end{tabular}

(Takara Bio, Inc., Otsu, Japan) in an iCycler iQ5 (Bio-Rad Laboratories, Inc., Hercules, CA, USA). This system automatically monitors the binding of fluorescent SYBR Green dye to double-stranded DNA during each PCR amplification cycle. PCR was performed in a $10 \mu 1$ reaction system. The PCR amplification procedure started at $50^{\circ} \mathrm{C}$ for $2 \mathrm{~min}$ and $95^{\circ} \mathrm{C}$ for $10 \mathrm{~min}$, followed by 40 cycles at $95^{\circ} \mathrm{C}$ for $15 \mathrm{sec}$, $60^{\circ} \mathrm{C}$ for $60 \mathrm{sec}$ and $72^{\circ} \mathrm{C}$ for $15 \mathrm{sec}$, and ended at $55^{\circ} \mathrm{C}$ for $30 \mathrm{sec}$. Dissociation curves were identified for the PCR products, and the $2^{-\Delta \Delta \mathrm{Cq}}$ method was used to analyze the mRNA levels (15). The primer sequences used for RT-PCR were listed in Table II.

Statistical analysis. SPSS 19.0 (IBM Corp., Armonk, NY, USA) was used for statistical analyses. Continuous data were presented as the mean \pm standard error. The comparison between groups was performed using a one-way analysis of variance or Kruskal-Wallis test, based on the homogeneity of variance. Multiple comparisons among groups were performed using the Student-Neuman-Keuls method. $\mathrm{P} \leq 0.05$ was considered to indicate a statistically significant difference.

\section{Results}

Alterations in CSF ET-1 expression levels. The clinical data of enrolled patients were summarized in Table III. The ET-1 levels in the CSF samples that were collected within seven-time frames following the onset of SAH are presented in Table IV. The ET-1 levels in CSF appeared to increase in the initial five days, reaching a peak within 3 to 5 days after onset of $\mathrm{SAH}$, but then gradually subsided. However, comparison between the seven groups showed no significant difference $(\mathrm{P}>0.05)$.

Contraction of arteries incubated with hemorrhagic CSF of different concentrations. In order to determine the best
Table IV. ET-1 expression levels in the hemorrhagic CSF samples.

\begin{tabular}{lc}
\hline Sampling time (T; days) & ET-1 $(\mathrm{pg} / \mathrm{ml})$ \\
\hline $\mathrm{T} \leq 1.5$ & $93.78 \pm 13.10$ \\
$1.5<\mathrm{T} \leq 2.5$ & $105.01 \pm 17.28$ \\
$2.5<\mathrm{T} \leq 3$ & $102.74 \pm 9.58$ \\
$3<\mathrm{T} \leq 5$ & $107.54 \pm 18.98$ \\
$5<\mathrm{T} \leq 7$ & $102.18 \pm 12.58$ \\
$7<\mathrm{T} \leq 10$ & $104.02 \pm 17.42$ \\
$\mathrm{~T}>10$ & $91.75 \pm 4.14$ \\
\end{tabular}

ET-1, endothelin-1; CSF, cerebrospinal fluid.

functional concentration, the hemorrhagic CSF was diluted in MOPS buffer and classified into three different concentrations (25, 50 or $100 \%)$. Rat basilar arteries were incubated with CSF of different concentrations for $12 \mathrm{~h}$, and in vitro contraction responses to ET-1 or S6c were observed. Statistical analysis demonstrated a positive association between the concentration and contraction degree, with a significant difference $(\mathrm{P}<0.05)$. Based on this result, $100 \%$ hemorrhagic CSF to was used at the culture media (data not shown).

Contraction of arteries for different incubation durations. The $\mathrm{E}_{\max }$ and $\mathrm{pEC}_{50}$ of unin. cubated fresh arteries and those of arteries incubated with clear CSF or hemorrhagic CSF for 6,12 or $24 \mathrm{~h}$ are presented in Table V. The contraction curves are presented in Figs. 1 and 2. In unincubated fresh arteries, ET-1 induced significant vasoconstriction, while S6c resulted in no vasoconstrictive effects.

After a $6 \mathrm{~h}$ incubation, all of the artery rings contracted, and those cultivated in clear CSF exhibited a more marked contraction. Statistical analysis demonstrated significant differences in the context of S6c concentrations ranging from $10^{-9.5}$ to $10^{-7.5} \mathrm{~mol} / 1$, or ET-1 concentrations ranging from $10^{-10}$ to $10^{-8.5} \mathrm{~mol} / \mathrm{l}$ (Fig. $1 \mathrm{~A}$ ).

After a $12 \mathrm{~h}$ incubation, all of the artery rings contracted, and those cultivated in hemorrhagic CSF demonstrated a larger contraction. Statistical analysis revealed significant differences in the context of S6c concentrations ranging from $10^{-9.5}$ to $10^{-8.5} \mathrm{~mol} / 1$, or ET-1 concentrations ranging from $10^{-9.5}$ to $10^{-7.5} \mathrm{~mol} / \mathrm{l}$ (Fig. $1 \mathrm{~B}$ ).

After a $24 \mathrm{~h}$ incubation, all of the artery rings contracted, and those cultivated in hemorrhagic CSF exhibited a more 
Table V. $\mathrm{E}_{\max }$ and $\mathrm{pEC}_{50}$ of artery rings.

\begin{tabular}{|c|c|c|c|c|c|c|c|}
\hline \multirow[b]{2}{*}{ Incubation duration } & \multirow[b]{2}{*}{ Incubation medium } & \multicolumn{3}{|c|}{ S6c } & \multicolumn{3}{|c|}{ ET-1 } \\
\hline & & $\mathrm{n}$ & $\mathrm{E}_{\max }\left(\% \mathrm{~K}^{+}\right)$ & $\mathrm{pEC}_{50}$ & $\mathrm{n}$ & $\mathrm{E}_{\max }\left(\% \mathrm{~K}^{+}\right)$ & $\mathrm{pEC}_{50}$ \\
\hline Control & Not incubated & 7 & $0 \pm 0.00$ & $0 \pm 0.00$ & 7 & $156.1 \pm 8.71$ & $8.9 \pm 0.12$ \\
\hline \multirow[t]{2}{*}{$6 \mathrm{~h}$} & SAH & 7 & $51.43 \pm 19.64$ & $9.6 \pm 0.24$ & 7 & $156.1 \pm 15.81$ & $8.5 \pm 0.05$ \\
\hline & NPH & 7 & $122.0 \pm 15.85$ & $9.2 \pm 0.07$ & 7 & $170.0 \pm 31.85$ & $9.3 \pm 0.07$ \\
\hline \multirow[t]{2}{*}{$12 \mathrm{~h}$} & SAH & 7 & $99.00 \pm 28.89$ & $9.7 \pm 0.14$ & 7 & $153.0 \pm 16.53$ & $9.4 \pm 0.08$ \\
\hline & NPH & 7 & $77.14 \pm 17.73$ & $9.5 \pm 0.01$ & 7 & $137.7 \pm 8.26$ & $9.5 \pm 0.06$ \\
\hline \multirow[t]{2}{*}{$24 \mathrm{~h}$} & SAH & 7 & $199.3 \pm 10.70$ & $9.6 \pm 6.82$ & 7 & $242.1 \pm 33.13$ & $9.7 \pm 7.04$ \\
\hline & NPH & 7 & $132.3 \pm 7.00$ & $9.7 \pm 0.18$ & 7 & $132.0 \pm 13.78$ & $9.7 \pm 0.11$ \\
\hline
\end{tabular}

$\mathrm{n}$ indicates the number of samples in each group. NPH, clear cerebrospinal fluid; SAH, subarachnoid hemorrhagic cerebrospinal fluid; ET-1, endothelin-1; S6c, sarafotoxins 6c.

marked contraction. Statistical analysis demonstrated significant differences in the context of S6c concentrations ranging from $10^{-9}$ to $10^{-7.5} \mathrm{~mol} / \mathrm{l}$, or ET-1 concentrations ranging from $10^{-9}$ to $10^{-7} \mathrm{~mol} / \mathrm{l}$ (Fig. $1 \mathrm{C}$ ).

Contraction response to S6c or ET-1. In arteries incubated with hemorrhagic CSF, S6c and ET-1 both induced vasoconstriction. Following the administration of S6c, the contraction degree was positively associated with the incubation period. When compared to fresh arteries, statistical analysis revealed significant differences in the context of S6c concentrations, ranging from $10^{-9.5}$ to $10^{-7.5} \mathrm{~mol} / \mathrm{l}$; there was also a significant difference in contraction degree between arteries incubated for 12 or $24 \mathrm{~h}$ (Fig. 2). Following the administration of ET-1, the contraction of arteries incubated for $6 \mathrm{~h}$ were not significantly different compared with the fresh arteries, and the arteries incubated for $24 \mathrm{~h}$ demonstrated the most remarkable contraction; statistical analysis revealed a significant difference in contraction degree between 24-h incubated arteries and fresh arteries in the context of a ET-1 concentration ranging from $10^{-9.5}$ to $10^{-7} \mathrm{~mol} / \mathrm{l}$.

Expression of $E T_{A}$ and $E T_{B} m R N A$. The detected expression levels of $\mathrm{ET}_{\mathrm{A}}$ and $\mathrm{ET}_{\mathrm{B}}$ mRNA are summarized in Table VI and Fig. 3. The expression levels of $\mathrm{ET}_{\mathrm{A}} \mathrm{mRNA}$ in the incubation groups were significantly higher compared with the control group $(\mathrm{P}<0.05)$. The expressions level of $\mathrm{ET}_{\mathrm{B}} \mathrm{mRNA}$ in the hemorrhagic CSF-incubation group was significantly higher compared with the control group $(\mathrm{P}<0.01)$, while there was no significant difference in the expression level of $\mathrm{ET}_{\mathrm{B}} \mathrm{mRNA}$ between the clear CSF-incubated arteries and the control arteries $(\mathrm{P}>0.05)$. There was no significant difference in the expression levels of $\mathrm{ET}_{\mathrm{A}}$ or $\mathrm{ET}_{\mathrm{B}}$ mRNA between the hemorrhagic CSF-incubated arteries and the clear CSF-incubated arteries $(\mathrm{P}>0.05)$.

\section{Discussion}

CVS is a serious complication of SAH, which may lead to fatal outcomes. The pathogenetic mechanisms remain poorly understood (16). Previous studies have demonstrated how vasospasm may develop following SAH, which involves altered expression levels of various vasoactive substances and specific receptors, as well as the matrix metalloproteinase family, inflammatory pathways, altered metal ion concentrations in CSF and high cholesterol levels (17-19). Among the mechanisms noted above, an increased level of contractile vasoactive substances and unregulated expression of their receptors are the most immediate causes for CVS following SAH. As a well-established, potent and long-lasting vasoconstrictor, ET-1 serves a crucial role in regulating the vascular tension (20). Previous studies have demonstrated that ET-1 levels in both plasma and CSF may increase in patients with SAH (21), and ET-1 causes dose-dependent vasoconstriction in animal models (7). The present study also drew similar conclusions, with the results indicating that ET-1 levels in the CSF of patients with SAH increased, and arteries incubated with hemorrhagic CSF from patients with SAH constricted in a dose-dependent manner in response to ET-1 and S6c. The present study used hemorrhagic CSF from patients with SAH to incubate rat basilar arteries, as this can better mimic the reaction of cerebral vessels of patients following $\mathrm{SAH}$ onset (22). However, the definitive pathogenic effects of ET-1 in CVS remain unclear. In the current study, the dynamic alterations in ET-1 expression in the CSF of SAH patients were demonstrated, and the contractility and expression levels of endothelin receptors in rat cerebral arteries incubated in various conditions were investigated.

Suzuki et al (23) revealed that the ET-1 expression levels in both the plasma and CSF of patients with SAH classified as Fisher grade III to IV were significantly higher, compared with those in patients with SAH classified as Fisher grade I or II. The present study only included patients with SAH classified as Fisher grade III or IV, who were more prone to develop CVS; CSF samples were collected within seven-time frames covering 0-10 days after SAH onset to observe the dynamic alterations in ET-1 levels. The findings of the current study indicated that the ET-1 expression levels in CSF increased in the initial 5 days, reaching a peak within 3 to 5 days following SAH onset, and then gradually subsided. It was speculated that these alterations may be due to a sequential process including blood flowing into the 

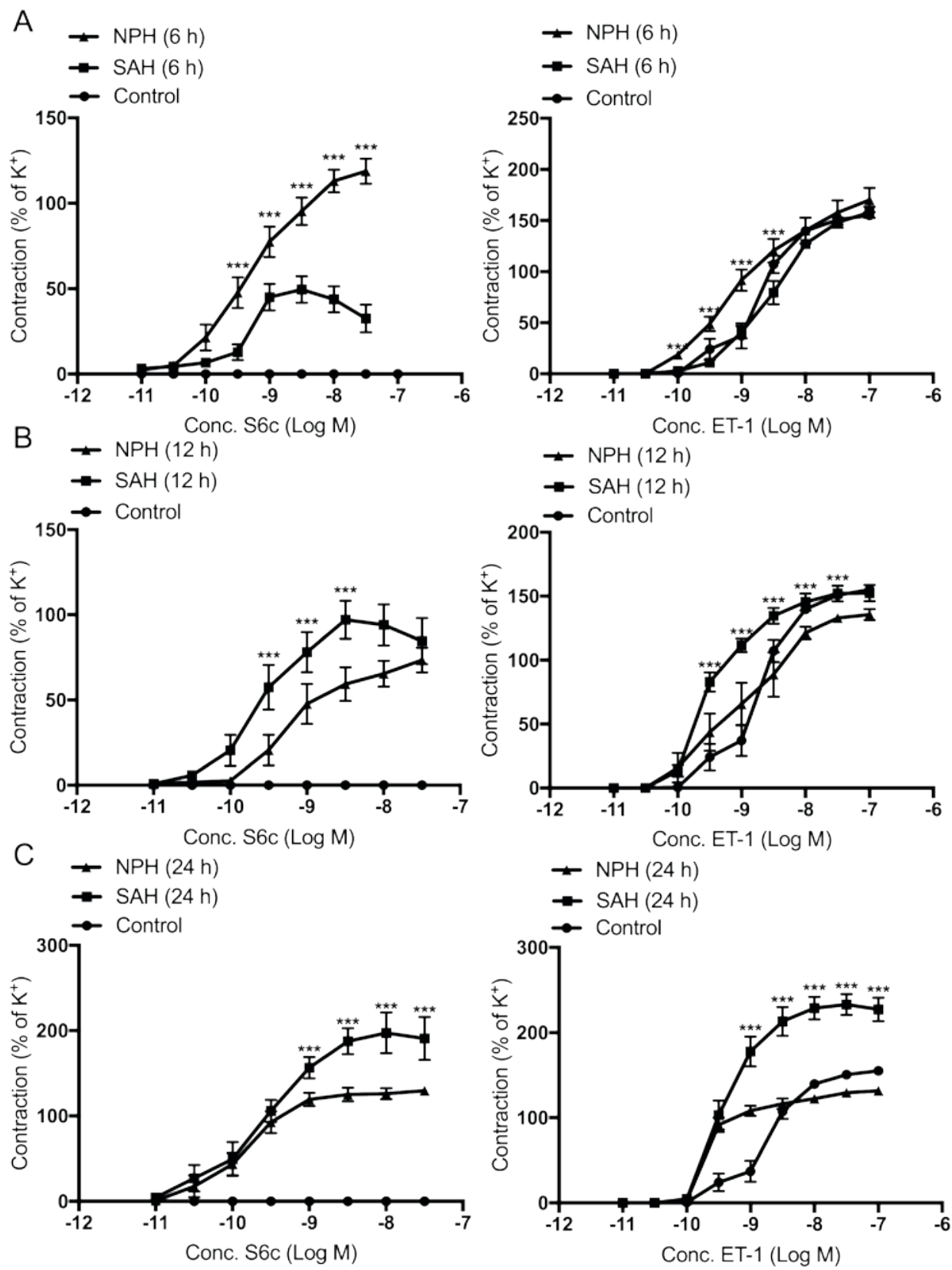

Figure 1. Contraction curves following the administration of S6c or ET-1 for (A) 6, (B) 12 or (C) $24 \mathrm{~h}$. The control groups were fresh arteries and not incubated. $\mathrm{NPH}$ or SAH group means arteries were incubated with clear CSF or hemorrhagic CSF, and control group means arteries were not incubated. For each group, $\mathrm{n}=7$. ${ }^{* * * *} \mathrm{P}<0.05$ vs. control group. CSF, cerebrospinal fluid; NPH, clear CSF; SAH, subarachnoid hemorrhagic CSF; Conc., concentration; ET-1, endothelin-1; S6c, sarafotoxins 6c.
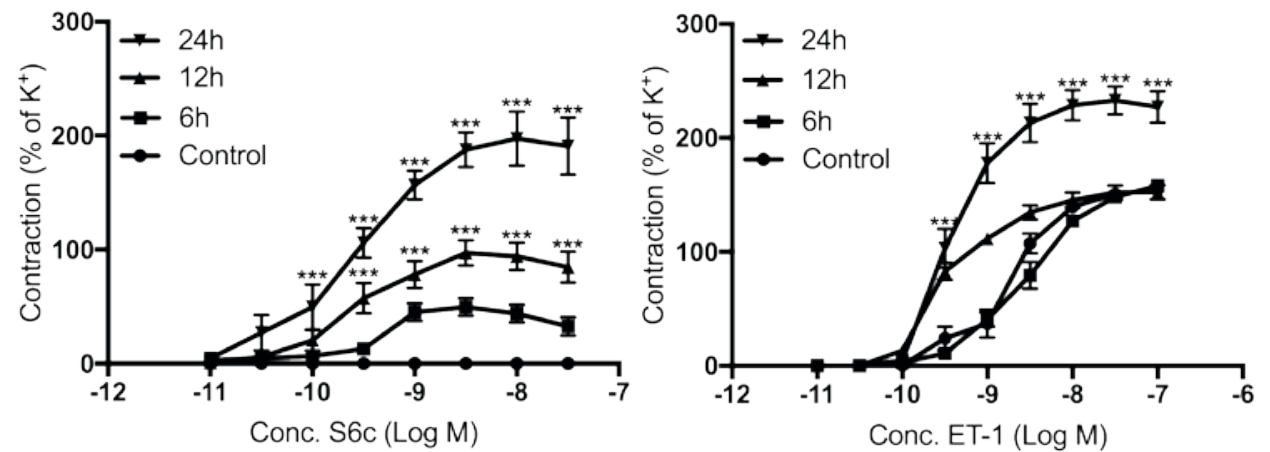

Figure 2. Contraction curves of vessels in the SAH group incubated for 6, 12 or $24 \mathrm{~h}$ following the administration of S6c or ET-1. The control groups were fresh arteries and not incubated. For each group, $\mathrm{n}=7$. ${ }^{* * *} \mathrm{P}<0.05$ vs. control group. Conc., concentration; ET-1, endothelin-1; S6c, sarafotoxins $6 \mathrm{c}$. 
Table VI. Expression levels of $\mathrm{ET}_{\mathrm{A}}$ and $\mathrm{ET}_{\mathrm{B}} \mathrm{mRNA}$.

\begin{tabular}{|c|c|c|c|c|}
\hline \multirow[b]{2}{*}{ Groups } & \multicolumn{2}{|r|}{$\mathrm{ET}_{\mathrm{B}} \mathrm{mRNA}$} & \multicolumn{2}{|r|}{$\mathrm{ET}_{\mathrm{A}} \mathrm{mRNA}$} \\
\hline & $\mathrm{n}$ & $\begin{array}{c}\text { Relative } \\
\text { expression } \\
\text { level }\end{array}$ & $\mathrm{n}$ & $\begin{array}{c}\text { Relative } \\
\text { expression } \\
\text { level }\end{array}$ \\
\hline Control & 5 & $0.0229 \pm 0.0041$ & 5 & $0.0136 \pm 0.0038$ \\
\hline $\mathrm{NPH}$ & 4 & $0.0808 \pm 0.0242$ & 5 & $0.2375 \pm 0.0875$ \\
\hline $\mathrm{SAH}$ & 5 & $0.1531 \pm 0.0235$ & 5 & $0.2606 \pm 0.0644$ \\
\hline
\end{tabular}

$\mathrm{n}$ indicates the number of samples in each group. The control groups were fresh arteries and not incubated. NPH, clear cerebrospinal fluid; $\mathrm{SAH}$, subarachnoid hemorrhagic cerebrospinal fluid; $\mathrm{ET}_{\mathrm{A}}$, endothelin receptor type $\mathrm{A} ; \mathrm{ET}_{\mathrm{B}}$, endothelin receptor type $\mathrm{B}$.

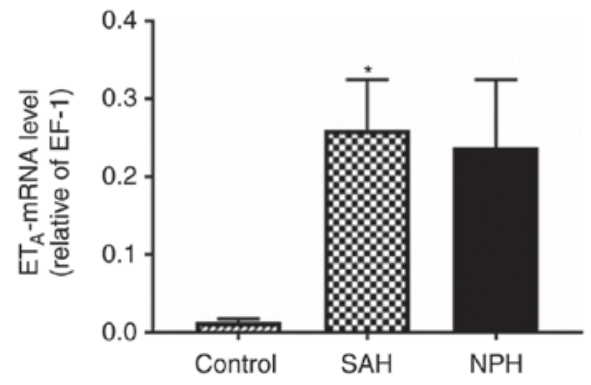

$\mathrm{ET}_{\mathrm{A}}$ receptor expression on arteries cultured for $24 \mathrm{~h}$

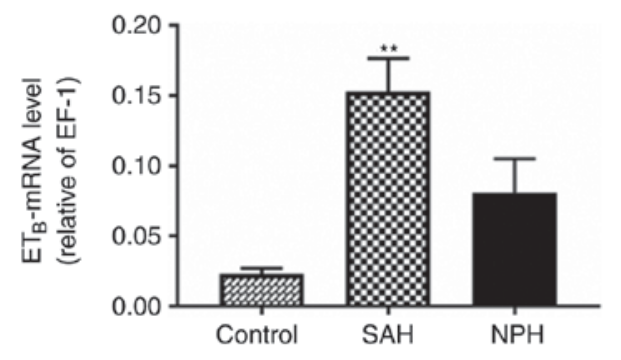

$\mathrm{ET}_{\mathrm{B}}$ receptor expression on arteries cultured for $24 \mathrm{~h}$

Figure 3. Relative expression levels of $\mathrm{ET}_{\mathrm{A}}$ and $\mathrm{ET}_{\mathrm{B}} \mathrm{mRNA}$. The control groups were fresh arteries and not incubated. The reference gene was elongation factor 1 alpha $(E F 1-\alpha)$. For each group, $n=5 .{ }^{*} \mathrm{P}<0.05,{ }^{* *} \mathrm{P}<0.01$ vs. control group. CSF cerebrospinal fluid; NPH, clear CSF; SAH, subarachnoid hemorrhagic CSF.

subarachnoid space, erythrocyte splitting, and their splitting products, such as oxyhemoglobin and oxygenase-1. These can stimulate cerebral vessels both physically and chemically $(24,25)$. Furthermore, previous studies demonstrated that patients with SAH may be at a high risk of developing CVS within 4-10 days following aneurysm rupture (3). This clinical phenomenon is consistent with the results of the present study, in that the time period of the higher CVS risk was similar to the higher levels of ET-1 detected in the CSF of SAH patients. The peak expression of ET-1 in the CSF of SAH patients appeared within 3-5 days and remained at a high level until 10 days after SAH onset. Therefore, it was speculated that ET-1 expression in the CSF may be a potential biomarker to predict CVS following SAH. However, statistical analysis revealed no significant difference, which may be due to the limited sample size; therefore, the exact role of ET-1 expression in patients with SAH requires further research.

To evaluate the expression of endothelin receptors and the arterial contractility, an in vitro experiment was performed using artery samples isolated from rat models. The arterial rings were incubated with hemorrhagic CSF or clear CSF, and ET-1 and S6c were administered to induce arterial contraction. It was demonstrated that S6c induced a significant contraction in CSF-incubated arteries but not in fresh arteries, whereas ET-1 induced contraction in both CSF-incubated and fresh arteries. A potential explanation for this phenomenon is that $\mathrm{S} 6 \mathrm{c}$ is a selective $\mathrm{ET}_{\mathrm{B}}$ receptor agonist, and $\mathrm{ET}_{\mathrm{B}}$ receptors are infrequently expressed in fresh vessels. However, they may greatly increase following CSF incubation. Nevertheless, ET-1 induces arterial contraction by both $\mathrm{ET}_{\mathrm{A}}$ receptors and $\mathrm{ET}_{\mathrm{B}}$ receptors, and $\mathrm{ET}_{\mathrm{A}}$ receptors are widely expressed in both fresh and CSF-incubated arteries (26). In the present study, as ET-1 or S6c concentrations increased, the arterial contraction increased. In arteries incubated in clear CSF, an incubation period of $6 \mathrm{~h}$ was associated with the most obvious arterial contraction, whereas in arteries incubated in hemorrhagic CSF, an incubation period of 12 or $24 \mathrm{~h}$ was associated with the strongest arterial contraction, and the contraction degree was associated with the incubation duration and CSF concentration. This discrepancy may be because there were not only vasoconstrictors but also a small quantity of short-acting vasodilators in hemorrhagic CSF $(27,28)$.

Furthermore, significantly elevated expression levels of both $\mathrm{ET}_{\mathrm{A}}$ and $\mathrm{ET}_{\mathrm{B}}$ mRNA in arteries incubated with hemorrhagic CSF were detected, compared with the expression levels in fresh arteries. However, there was no significant difference in the expression levels of $\mathrm{ET}_{\mathrm{A}}$ or $\mathrm{ET}_{\mathrm{B}} \mathrm{mRNA}$ between the hemorrhagic CSF-incubated arteries and the clear CSF-incubated arteries. Zuccarello et al (29) proposed that $\mathrm{ET}_{\mathrm{A}}$ receptors induce vasoconstriction, while $\mathrm{ET}_{\mathrm{B}}$ receptors mediate vasodilation in physiological conditions. Certain reports have also speculated that SAH may result in an altered endothelial-dependent action of ET-1 and may lead to the upregulation of $\mathrm{ET}_{\mathrm{B}}$ receptors in vascular smooth muscle cells, thereby contributing to vasoconstriction $(30,31)$. It was therefore considered that the enhanced contractility of hemorrhagic CSF-incubated arteries in the present study may have been more associated with upregulated expression of $\mathrm{ET}_{\mathrm{B}}$ receptors, rather than $\mathrm{ET}_{\mathrm{A}}$ receptors. In previous studies, scholars reported that clazosentan, a nonpeptide selective $\mathrm{ET}_{\mathrm{A}}$ receptor antagonist, significantly reduces the occurrence of CVS following SAH, but that it did not improve clinical outcomes (32-34). This may be because this selective $\mathrm{ET}_{\mathrm{A}}$ receptor antagonist cannot antagonize $\mathrm{ET}_{\mathrm{B}}$ receptors, which may serve a more important role in the pathogenesis of CVS following SAH (32). According to the result of the present study and the unsatisfactory treatment effect of clazosentan, the therapeutic efficacy of ET receptor antagonists acting on both $\mathrm{ET}_{\mathrm{A}}$ receptor and $\mathrm{ET}_{\mathrm{B}}$ receptor requires further study.

The role of ET-1 and its receptors in the pathogenetic mechanism of CVS remains unclear. Previous studies have indicated that the mitogen-activated protein kinase (MAPK) signaling pathway may be a promising research avenue, as the activation of MAPKs may increase the expression of endothelin 
receptors (35). However, the role of MAPK phosphatases, the endogenous MAPK inhibitors, has not been investigated in CVS. Additionally, the elevated expression of $\mathrm{ET}_{\mathrm{A}}$ receptors was reported to be associated with the activation of extracellular regulated protein kinase in vascular endothelial cells, as well as intracellular protein kinase $\mathrm{C}$, protein kinase $\mathrm{A}$ and phosphatidylinositol 3-kinase (36). The causative role of ET-1 and its receptors in CVS warrants further research.

The sample size in the current study was limited, and in the future studies the cohort size of patients with SAH should be expanded to obtain more CSF samples. Additionally, hemodynamic parameters will be recorded using CT perfusion techniques, including cerebral blood flow, cerebral blood volume, and mean transit time, to further investigate the effects of ET-1 on cerebral vessels, particularly microvessels.

In conclusion, ET-1 and its receptors may be involved in the pathogenic mechanism of CVS following SAH. It was demonstrated that the dynamic alterations in ET-1 expression levels in CSF were parallel with the clinical development of CVS in patients with SAH, indicating that ET-1 may be a helpful biomarker for the prediction and diagnosis of CVS. The expression levels of $\mathrm{ET}_{\mathrm{A}}$ and $\mathrm{ET}_{\mathrm{B}}$ mRNA were upregulated in CSF following SAH, which may be associated with the hypercontractility of cerebral arteries. ET-1 receptors may provide novel therapeutic targets in CVS.

\section{Acknowledgements}

Not applicable.

\section{Funding}

The present study was supported by the National Natural Science Foundation of China (Grant no. 81271227) and the National Key Technology R\&D Program of China (Grant no. 2014BAI04B05).

\section{Availability of data and materials}

All data generated and analyzed during the present study is included in this published article.

\section{Authors' contributions}

GL, YXC and CX conceived and designed the experiments. YWC, WL and XD performed the experiments. YWC, WL and RJ analyzed the data. HY and XL helped testing the levels of ET-1 in the CSF samples. JL designed the concentration gradient of the drugs. YWC wrote the manuscript. All authors have read and approved this manuscript.

\section{Ethics approval and consent to participate}

The present study was approved by the Institutional Review Board and Ethics Committee of the First Affiliated Hospital of Xi'an Jiaotong University (Xi'an, China; approval no. 2016-074). Animal experiments were approved by the Animal Experiment Management Committee of Xi'an Jiaotong University (Xi'an, China), and all measures were taken to minimize animal discomfort.

\section{Patient consent for publication}

Not applicable.

\section{Competing interests}

The authors declare that they have no competing interests.

\section{References}

1. de Rooij NK, Linn FH, van der Plas JA, Algra A and Rinkel GJ: Incidence of subarachnoid haemorrhage: A systematic review with emphasis on region, age, gender and time trends. J Neurol Neurosurg Psychiatry 78: 1365-1372, 2007.

2. Bederson JB, Connolly ES Jr, Batjer HH, Dacey RG, Dion JE, Diringer MN, Duldner JE Jr, Harbaugh RE, Patel AB and Rosenwasser RH; American Heart Association: Guidelines for the management of aneurysmal subarachnoid hemorrhage: A statement for healthcare professionals from a special writing group of the stroke council, American heart association. Stroke 40: 994-1025, 2009.

3. Cossu G, Messerer M, Oddo M and Daniel RT: To look beyond vasospasm in aneurysmal subarachnoid haemorrhage. Biomed Res Int 2014: 628597, 2014.

4. Mascia L, Fedorko L, Stewart DJ, Mohamed F, terBrugge K, Ranieri VM and Wallace MC: Temporal relationship between endothelin-1 concentrations and cerebral vasospasm in patients with aneurysmal subarachnoid hemorrhage. Stroke 32: 1185-1190, 2001.

5. Cao L, Xu CB, Zhang Y, Cao YX and Edvinsson L: Secondhand smoke exposure induces Raf/ERK/MAPK-mediated upregulation of cerebrovascular endothelin ETA receptors. BMC Neurosci 12: 109, 2011.

6. Xie A, Aihara Y, Bouryi VA, Nikitina E, Jahromi BS, Zhang ZD, Takahashi M and Macdonald RL: Novel mechanism of endothelin-1-induced vasospasm after subarachnoid hemorrhage. J Cereb Blood Flow Metab 27: 1692-1701, 2007.

7. Zubkov AY, Rollins KS, Parent AD, Zhang J and Bryan RM Jr: Mechanism of endothelin-1-induced contraction in rabbit basilar artery. Stroke 31: 526-533, 2000.

8. Hino A, Tokuyama Y, Kobayashi M, Yano M, Weir B, Takeda J, Wang X, Bell GI and Macdonald RL: Increased expression of endothelin $B$ receptor mRNA following subarachnoid hemorrhage in monkeys. J Cereb Blood Flow Metab 16: 688-697, 1996.

9. Itoh S, Sasaki T, Asai A and Kuchino Y: Prevention of delayed vasospasm by an endothelin ETA receptor antagonist, BQ-123: Change of ETA receptor $m$ RNA expression in a canine subarachnoid hemorrhage model. J Neurosurg 81: 759-764, 1994.

10. Zuccarello M, Boccaletti R, Romano A and Rapoport RM: Endothelin B receptor antagonists attenuate subarachnoid hemorrhage-induced cerebral vasospasm. Stroke 29: 1924-1929, 1998.

11. Kikkawa Y, Matsuo S, Kameda K, Hirano M, Nakamizo A, Sasaki T and Hirano K: Mechanisms underlying potentiation of endothelin-1-induced myofilament $\mathrm{Ca}(2+)$ sensitization after subarachnoid hemorrhage. J Cereb Blood Flow Metab 32: 341-352, 2012.

12. Assenzio B, Martin EL, Stankevicius E, Civiletti F, Fontanella M, Boccaletti R, Berardino M, Mazzeo A, Ducati A, Simonsen U and Mascia L: Cerebrospinal fluid from patients with subarachnoid haemorrhage and vasospasm enhances endothelin contraction in rat cerebral arteries. PLoS One 10: e0116456, 2015.

13. Ogungbo B: The world federation of neurological surgeons scale for subarachnoid hemorrhage. Surg Neurol 59: 236-238, 2003.

14. Fisher CM, Kistler JP and Davis JM: Relation of cerebral vasospasm to subarachnoid hemorrhage visualized by computerized tomographic scanning. Neurosurgery 6: 1-9, 1980.

15. Livak KJ and Schmittgen TD: Analysis of relative gene expression data using real-time quantitative PCR and the 2(-Delta Delta C(T)) method. Methods 25: 402-408, 2001.

16. Bacigaluppi S, Zona G, Secci F, Spena G, Mavilio N, Brusa G, Agid R, Krings T, Ottonello G and Fontanella M: Diagnosis of cerebral vasospasm and risk of delayed cerebral ischemia related to aneurysmal subarachnoid haemorrhage: An overview of available tools. Neurosurg Rev 38: 603-618, 2015.

17. Mehta V, Russin J, Spirtos A, He S, Adamczyk P, Amar AP and Mack WJ: Matrix metalloproteinases in cerebral vasospasm following aneurysmal subarachnoid hemorrhage. Neurol Res Int 2013: 943761, 2013. 
18. Tuttolomondo A, Di Sciacca R, Di Raimondo D, Pedone C, La Placa S, Pinto A and Licata G: Effects of clinical and laboratory variables and of pretreatment with cardiovascular drugs in acute ischaemic stroke: A retrospective chart review from the GIFA study. Int J Cardiol 151: 318-322, 2011.

19. Tuttolomondo A, Pecoraro R, Casuccio A, Di Raimondo D, Buttà C, Clemente G, Della Corte V, Guggino G, Arnao V, Maida C, et al: Peripheral frequency of CD4+ CD28- cells in acute ischemic stroke: Relationship with stroke subtype and severity markers. Medicine (Baltimore) 94: e813, 2015.

20. Barton M: The discovery of endothelium-dependent contraction: The legacy of Paul M. Vanhoutte. Pharmacol Res 63: 455-462, 2011.

21. Kessler IM, Pacheco YG, Lozzi SP, de Araújo AS Jr, Onishi FJ and de Mello PA: Endothelin-1 levels in plasma and cerebrospinal fluid of patients with cerebral vasospasm after aneurysmal subarachnoid hemorrhage. Surg Neurol 64 (Suppl 1): S1:2-5; discussion S1:5, 2005.

22. Peterson JW, Kwun BD, Teramura A, Hackett JD, Morgan JA, Nishizawa S, Bun T and Zervas NT: Immunological reaction against the aging human subarachnoid erythrocyte. A model for the onset of cerebral vasospasm after subarachnoid hemorrhage. J Neurosurg 71: 718-726, 1989.

23. Suzuki R, Masaoka H, Hirata Y, Marumo F, Isotani E and Hirakawa K: The role of endothelin-1 in the origin of cerebral vasospasm in patients with aneurysmal subarachnoid hemorrhage. J Neurosurg 77: 96-100, 1992.

24. Wang KC, Tang SC, Lee JE, Lai DM, Huang SJ, Hsieh ST, Jeng JS and Tu YK: Prognostic value of intrathecal heme oxygenase-1 concentration in patients with Fisher Grade III aneurysmal subarachnoid hemorrhage. J Neurosurg 121: 1388-1393, 2014.

25. Kolias AG, Sen J and Belli A: Pathogenesis of cerebral vasospasm following aneurysmal subarachnoid hemorrhage: Putative mechanisms and novel approaches. J Neurosci Res 87: 1-11, 2009

26. Cao L, Ping NN, Cao YX, Li W, Cai Y, Warfvinge K and Edvinsson L: The effects of MEK1/2 inhibition on cigarette smoke exposure-induced ET receptor upregulation in rat cerebral arteries. Toxicol Appl Pharmacol 304: 70-78, 2016.

27. Onoue H, Kaito N, Akiyama M, Tomii M, Tokudome S and Abe T: Altered reactivity of human cerebral arteries after subarachnoid hemorrhage. J Neurosurg 83: 510-515, 1995.
28. Wang Y, Tian Y, Wang D, Wei H, Zhao Z, Jiang R, Yue S and Zhang J: High Angiopoietin-1 levels predict a good functional outcome within $72 \mathrm{~h}$ of an aneurysmal subarachnoid hemorrhage: A prospective study from a single center. J Neurol Sci 356: 72-76, 2015.

29. Zuccarello M, Lewis AI and Rapoport RM: Endothelin ETA and ETB receptors in subarachnoid hemorrhage-induced cerebral vasospasm. Eur J Pharmacol 259: R1-R2, 1994.

30. Clozel M, Gray GA, Breu V, Löffler BM and Osterwalder R: The endothelin ETB receptor mediates both vasodilation and vasoconstriction in vivo. Biochem Biophys Res Commun 186 867-873, 1992.

31. Hansen-Schwartz J, Hoel NL, Zhou M, Xu CB, Svendgaard NA and Edvinsson L: Subarachnoid hemorrhage enhances endothelin receptor expression and function in rat cerebral arteries. Neurosurgery 52: 1188-1194, 2003.

32. Macdonald RL, Kassell NF, Mayer S, Ruefenacht D, Schmiedek P, Weidauer S, Frey A, Roux S and Pasqualin A; CONSCIOUS-1 Investigators: Clazosentan to overcome neurological ischemia and infarction occurring after subarachnoid hemorrhage (CONSCIOUS-1): Randomized, double-blind, placebo-controlled phase 2 dose-finding trial. Stroke 39: 3015-3021, 2008.

33. Macdonald RL, Higashida RT, Keller E, Mayer SA, Molyneux A Raabe A, Vajkoczy P, Wanke I, Bach D, Frey A, et al: Randomised trial of clazosentan, an endothelin receptor antagonist, in patients with aneurysmal subarachnoid hemorrhage undergoing surgical clipping (CONSCIOUS-2). Acta Neurochir Suppl 115: 27-31, 2013.

34. Macdonald RL, Higashida RT, Keller E, Mayer SA, Molyneux A, Raabe A, Vajkoczy P, Wanke I, Bach D, Frey A, et al: Randomized trial of clazosentan in patients with aneurysmal subarachnoid hemorrhage undergoing endovascular coiling. Stroke 43: 1463-1469, 2012

35. Suzuki H, Hasegawa Y, Kanamaru K and Zhang JH: Mitogen-activated protein kinases in cerebral vasospasm after subarachnoid hemorrhage: A review. Acta Neurochir Suppl 110: 133-139, 2011.

36. Chen QW, Edvinsson L and Xu CB: Role of ERK/MAPK in endothelin receptor signaling in human aortic smooth muscle cells. BMC Cell Biol 10: 52, 2009. 